JURNAL PEMBERDAYAAN DAN PENDIDIKAN

KESEHATAN

VOL. 1 NO. 01, DESEMBER 2021

DOI:
Ciptaan disebarluaskan di bawah

Lisensi Creative Commons Atribusi-

NonKomersial-BerbagiSerupa 4.0

Internasional.

\title{
Cuci Tangan Pakai Sabun Dan Vaksinasi
}

Tia Fitriani, Icca Stella Amalia, Hany Noviyanti, Iding Budiman, Apip Apriyanto, Ridwan Hilman

STIKes Kuningan

Email: tfitriani639@gmail.com

\begin{abstract}
Abstrak
Pendahuluan : Sejak ditetapkannya negara Indonesia sebagai darurat bencana corona berdasarkan saran dari WHO, maka pemerintah mengambil beberapa langkah yang ditetapkan sebagai kebijakan untuk pencegahan penularan Covid-19 ini. Tujuan kegiatan ini untuk mengetahui efektivitas cuci tangan pakai sabun dan vaksinasi untuk menghindari penularan Covid-19 di Desa Darma Kecamatan Darma Kabupaten Kuningan Tahun 202. Metode : Metode yang digunakan pada kegiatan ini adalah ceramah dengan menggunakan media power point. Instrumen penilaian terhadap pengetahuan responden yaitu menggunakan lembar kuesioner sebelum penyuluhan dan sesudah pelmyuluhan serta lembar evaluasi sebagai penilaian kegiatan. Hasil : Hasil evaluasi kegiatan menunjukkani bahwa sebagian besar peserta memiliki nilai post test lebih besar dibandingkan dengan nilai pre test baik untuk pertanyaan seputar covid-19 maupun vaksinasi. Kesimpulan : Kegiatan pemberian Komunikasi Informasi dan Edukasi (KIE) ini dilakukan sebagai upaya pencegahan penularan Virus Covid-19. Mengingat persebaran kasus ini terus meningkat maka berbagai upaya harus dilakukan guna mengurangi penyebarannya. Kegiatan ini dilakukan pada siswa siswi MI Yashuda 1 Darma dan MTSN 5 Kuningan dengan responden sebannyak 35 orang.
\end{abstract}

Kata kunci: Desa Darma, COVID-19, Vaksinasi, Ceramah, Kuningan

\section{PENDAHULUAN}

Kasus pneumonia misterius pertama kali dilaporkan di Wuhan, Provinsi Hubei, China pada Desember tahun 2019. Sumber penularan kasus ini masih belum diketahui pasti, tetapi kasus pertama dikaitkan dengan pasar ikan di Wuhan. Pada bulan Desember terdapat lima pasien yang dirawat dengan Acute Respiratory Distress Syndrome (ARDS). Tidak sampai satu bulan, penyakit ini telah menyebar di berbagai provinsi lain di China, Thailand, Jepang, dan Korea Selatan. Awalnya, penyakit ini dinamakan sementara sebagai 2019 novel coronavirus (2019-nCoV), kemudian WHO mengumumkan nama baru pada 11 Februari 2020 
JURNAL PEMBERDAYAAN DAN PENDIDIKAN

KESEHATAN

VOL. 1 NO. 01, DESEMBER 2021

DOI:
Ciptaan disebarluaskan di bawah

Lisensi Creative Commons Atribusi-

NonKomersial-BerbagiSerupa 4.0

Internasional.

yaitu Coronavirus Disease (Covid-19) yang disebabkan oleh virus Severe Acute Respiratory Syndrome Coronavirus-2 (SARS-CoV-2). Virus ini dapat ditularkan dari manusia ke manusia dan telah menyebar secara luas di China dan lebih dari 190 negara dan teritori lainnya.

Pada Tanggal 30 Januari 2020, telah terdapat 7.736 kasus terkonfirmasi Covid-19 di China, dan 86 kasus lain dilaporkan dari berbagai negara seperti Taiwan, Thailand, Vietnam, Malaysia, Nepal, Sri Lanka, Kamboja, Jepang, Singapura, Arab Saudi, Korea Selatan, Filipina, India, Australia, Kanada, Finlandia, Prancis, dan Jerman. Pada tanggal 12 Maret 2020, WHO mengumumkan Covid-19 sebagai pandemik. Kemudian hingga tanggal 23 April 2020, terdapat 2.549.632 kasus terkonfirmasi dan 175.825 jumlah kematian yang tersebar di 213 negara/kawasan di dunia.

Kasus Covid-19 pertama kali dilaporkan di Indonesia pada tanggal 2 Maret 2020 sejumlah dua kasus. Data 31 Maret 2020 menunjukkan kasus yang terkonfirmasi berjumlah 1.528 kasus dan 136 kasus kematian. Tingkat mortalitas Covid-19 di Indonesia sebesar 8,9\%, angka ini merupakan yang tertinggi di Asia Tenggara. Data terbaru pada tanggal 23 April 2020 kasus terkonfirmasi positif sebanyak 7.775 kasus dengan 647 kematian. Saat ini, penyebaran SARS-CoV-2 dari manusia ke manusia menjadi sumber transmisi utama sehingga penyebaran menjadi lebih agresif. Transmisi SARS-CoV-2 dari pasien simptomatik terjadi melalui droplet yang keluar saat batuk atau bersin.

Sejak ditetapkannya negara Indonesia sebagai darurat bencana corona berdasarkan saran dari WHO, maka pemerintah mengambil beberapa langkah yang ditetapkan sebagai kebijakan untuk pencegahan penularan Covid-19 ini. Pemerintah telah melakukan berbagai strategi dalam menghadapi covid 19 baik yang bersifat preventif (pencegahan) seperti memberlakukan PSBB (Mewa Ariani, Adi Setiyanto, 2020), promotif (pemberdayaan) seperti tidak merokok, berhenti mengkonsumsi alkohol, menerapkan pola hidup bersih dan sehat (Safitry, 2016), maupun kuratif (pengobatan) seperti anjuran presiden untuk memberikan avigan dan klorokuin dll (Prastyowati, 2020). Hal ini sudah menjadi kebijakan pemerintah berdasarkan pertimbangan-pertimbangan yang sudah melalui analisa yang mendalam. Kebijakan ini diharapkan mampu mengatasi masalah yang terjadi di masyarakat yang berorientasi pada pemenuhan kebutuhan dan kepentingan masyarakat. Salah satu usaha 
JURNAL PEMBERDAYAAN DAN PENDIDIKAN

KESEHATAN

VOL. 1 NO. 01, DESEMBER 2021

DOI:
Ciptaan disebarluaskan di bawah

Lisensi Creative Commons Atribusi-

NonKomersial-BerbagiSerupa 4.0

Internasional.

pemerintah nyata dalam pencegahan dan pengendalian Covid-19 adalah dengan pemberian vaksin melalui petugas kesehatan. (Letuna, 2021)

Pentingnya personal hygiene pula harus diterapkan pada masing-masing individu. Dengan melakukan personal hygiene seperti rajin mencuci tangan pakai sabun, dapat meminimalisir terjadinya penularan penyakit terutama covid-19. Menurut Indah (2020), pemerintah pula telah mencanangkan program pemberian vaksinasi Covid-19 kepada seluruh rakyat Indonesia. Sebanyak lebih dari 3 juta vaksin Covid-19 yang diproduksi oleh Sinovac yang merupakan produsen vaksin Covid-19 telah didatangkan pemerintah Indonesia dalam dua tahap pada periode I dan II. Periode I dengan jumlah 18,7 juta dosis untuk tenaga kesehatan; petugas publik yang tidak dapat menerapkan jaga jarak secara efektif dan sebanyak 21,5 juta untuk lansia (di atas umur 60 tahun). Periode II sebanyak 63,9 juta untuk masyarakat dengan risiko penularan tinggi, baik dari segi tempat tinggal atau kelas ekonomi dan sosial serta sebanyak 77,4 juta kepada masyarakat umum dengan pendekatan kluster sesuai ketersediaan vaksin (Litbang.kemkes, 2021).

Vaksin adalah antigen berupa mikroorganisme yang sudah mati, masih hidup tapi dilemahkan, masih utuh atau bagiannya, yang telah diolah, berupa toksin mikroorganisme yang telah diolah menjadi toksoid, protein rekombinan yang bila diberikan kepada seseorang akan menimbulkan kekebalan spesifik secara aktif terhadap penyakit infeksi tertentu (Yusuf, 2005)

Vaksin dilakukan melalui imunisasi aktif yang bertujuan menyiapkan tubuh lebih kebal, ketika terpapar lagi tubuh dapat mengenali dan meresponnya. Herd immunity (kekebalan kelompok) terbentuk jika sebagian masyarakat menerima vaksinasi. Berdasarkan survey penerimaan vaksin oleh masyarakat yang dilakukan pemerintah menunjukkan 64,8\% yang menerima dengan senng hati, 27,6\% meneima dengan pasif dan 7,6\% menolak semua $\operatorname{vaksin}($ RI, 2021).

\section{IDENTIFIKASI MASALAH}

Kasus Covid-19 di Kabupaten Kuningan menunjukkan jumlah yang signifikan dalam beberapa bulan terakhir. Penambahan jumlah kasus covid-19 ini tersebar di beberapa kecamatan di Kabupaten Kuningan. Hal ini disebabkan karena trend sebaran kasus pasien terkonfirmasi positif Covid-19 terus mengalami kenaikan. Desa Darma merupakan salah satu 
JURNAL PEMBERDAYAAN DAN PENDIDIKAN

KESEHATAN

VOL. 1 NO. 01, DESEMBER 2021

DOI:
Ciptaan disebarluaskan di bawah

Lisensi Creative Commons Atribusi-

NonKomersial-BerbagiSerupa 4.0

Internasional.

wilayah yang terkonfirmasi memiliki beberapa warga yang terkena virus covid-19. Tercatat beberapa bulan terakhir kasus covid-19 sudah mencapai lebih dari 20 orang.

Permasalahan di masyarakat masih banyak yang belum paham pencegahan penularan covid-19 ini diantaranya pentingnya menggunakan masker ketika keluar rumah, pentingnya personal hygiene, cuci tangan pakai sabun, physical distancing dan vaksinasi. Kebiasaan untuk menerapkan perilaku hidup bersih dan sehat bukan hal mudah, membutuhkan pemahaman dan motivasi dari individu sehingga setiap individu lebih disiplin dalam menerapkannya.

Berdasarkan permasalahan tersebut, maka penulis mengangkat topik Program Pengabdian Masyarakat Duta Perubahan Covid-19 Tentang Cuci Tangan Pakai Sabun dan Vaksinasi di MTSN 5 Kuningan \& MI Yashuda 1 Darma Desa Darma Kecamatan Darma, yaitu melakukan pengabdian masyarakat dengan memberikan edukasi dan promosi kesehatan mengenai pencegahan penularan Covid-19 melalui media poster tentang Perilaku Hidup Bersih dan Sehat (PHBS), Cuci Tangan Pakai Sabun (CTPS), Pentingnya Vaksinasi pada siswa dan siswi di MI YASHUDA 1 DARMA dan MTSN 5 Kuningan.

\section{METODE}

Pelaksanaan pengabdian masyarakat (pengmas) ini dilaksanakan pada 24-25 Agustus 2021 yang bertempat di MI YASHUDA 1 DARMA dan MTSN 5 Kuningan

Metode pelaksanaan dilakukan melalui beberapa tahap yaitu :

\section{1.) Perencanaan}

Pada tahap ini kegiatan yang dilakukan adalah :

a) Persiapan kuesioner pre test dan post test

b) Persiapan materi

c) Percetakan poster

d) Pembelian handwash, dan alat kebersihan

e) Kegiatan penyerahan poster dan alat kebersihan

\section{2) Pelaksanaan}

Kegiatan pengabdian masyarakat ini bertema Program Pengabdian Masyarakat Duta Perubahan Covid-19 Tentang Cuci Tangan Pakai Sabun (CTPS) pada siswa-siswi MI Yashuda 1 Darma di Desa Darma Kecamatan Darma Kabupaten Kuningan. Kegiatan ini 
JURNAL PEMBERDAYAAN DAN PENDIDIKAN

KESEHATAN

VOL. 1 NO. 01, DESEMBER 2021

DOI:
Ciptaan disebarluaskan di bawah

Lisensi Creative Commons Atribusi-

NonKomersial-BerbagiSerupa 4.0

Internasional.

dilakukan dengan memberikan edukasi/penyuluhan dengan media poster dan pemberian pre test dan post test yang diberikan bersamaan dalam kegiatan ini.

Sedangkan pada siswa-siswi MTSN 1 Darma dilakukan pemberian Komunikasi Informasi dan Edukasi (KIE) melalui penyampaian materi tentang vaksinasi, pembagian poster serta pemberian pre test dan post test. Kegiatan ini dilakukan dengan kerja sama pihakpihak yang berada di lingkungan sekolah.

\section{HASIL DAN PEMBAHASAN}

Kegiatan pengabdian berupa pemberian edukasi melalui penyampaian materi tentang cuci tangan pakai sabun dan vaksinasi menggunakan media poster juga disertai dengan pemberian hadiah bagi keaktifan peserta telah dilaksanakan pada tanggal 24-25 Agustus 2021. Tujuan kegiatan ini adalah sebagai bentuk antisipasi terhadap penyebaran virus COVID-19 yang merupakan ancaman kesehatan global pada saat ini. Kegiatan ini diterima dengan antusias oleh siswa-siswi dan pihak sekolah. Kegiatan pemberian edukasi dilaksanakan di dua sekolah dengan sasaran siswa siswi. Mengingat kluster anak-anak pula dapat terdampak covid-19 sehingga diperlukan komunikasi informasi dan edukasi (KIE) dengan metode yang mudah dipahami.

Kegiatan edukasi melalui media poster dilaksanakan mengingat kondisi saat ini yang tidak memungkinkan kegiatan pengabdian masyarakat mengumpulkan orang dalam jumlah banyak. Media yang disampaikan ini memuat informasi tentang pencegahan virus covid-19 melalui 5M (Mencuci tangan, Memakai masker, Menjaga Jarak, Menjauhi kerumunan, dan Mengurangi mobilitas), Manfaat vaksinasi, serta informasi tentang Perilaku Hidup Bersih dan Sehat (PHBS). Poster merupakan salah satu media promosi kesehatan dalam bentuk media cetak berisi pesan-pesan / informasi kesehatan yang biasanya di tempat-tempat umum (Halajur, 2018). Kegiatan pengabdian khususnya mengenai covid-19 diharapkan dapat dijalankan di semua daerah. Kerjasama institusi pendidikan dan pemerintah daerah harus terus digalakkan dalam mengatasi permasalahan ini. Kontribusi institusi pendidikan dalam memberikan edukasi kepada masyarakat sangat besar sekali peranannya melalui penggunaan media yang inovatif dan sesuai dengan kebutuhan masyarakat saat ini.

Kegiatan pengabdian masyarakat ini tidak hanya berupa edukasi tentang Perilaku Hidup Bersih dan Sehat (PHBS) dan vaksinasi tetapi dengan praktik langsung cara cuci 
JURNAL PEMBERDAYAAN DAN PENDIDIKAN KESEHATAN

VOL. 1 NO. 01, DESEMBER 2021

DOI:
Ciptaan disebarluaskan di bawah

Lisensi Creative Commons Atribusi-

NonKomersial-BerbagiSerupa 4.0

Internasional

tangan pakai sabun dengan baik dan benar serta pemutaran video terkait vaksin. Secara umum, kegiatan pengabdian ini berjalan dengan lancar dan mendapatkan sambutan yang baik dari masyarakat. Adapun hasil penelitian kegiatan sebagai berikut :

Tabel 1. Distribusi Frekuensi Pengetahuan dan Sikap Sebelum dan Sesudah Penyuluhan

\begin{tabular}{ccccc}
\hline & \multicolumn{2}{c}{ Sebelum Penyuluhan } & \multicolumn{2}{c}{ Sesudah Penyuluhan } \\
\hline Pengetahuan & Frekuensi & Persentase (\%) & Frekuensi & Persentase (\%) \\
\hline Kurang & 10 & 28,6 & 0 & 0 \\
Cukup & 9 & 25,7 & 0 & 0 \\
Baik & 16 & 45,7 & 35 & 100 \\
\hline Total & $\mathbf{3 5}$ & $\mathbf{1 0 0}$ & $\mathbf{3 5}$ & $\mathbf{1 0 0}$ \\
\hline Sikap & & & 0 & 0 \\
\hline Kurang & 10 & 28,6 & 0 & 100 \\
Cukup & 9 & 25,7 & 35 & $\mathbf{1 0 0}$ \\
Baik & 16 & 45,7 & $\mathbf{3 5}$ &
\end{tabular}

Berdasarkan tabel 1 dapat diketahui bahwa tingkat pengetahuan responden yang diukur melalui kuesioner pre test dan post test didapatkan hasil tingkat pengetahuan mereka dikategorikan baik setelah dilakukan penyuluhan. Dibuktikan dengan capaian persentase nilai pengetahuan $54,3 \%$ menjadi $100 \%$. Sedangkan hasil pengukuran sikap mengalami peningkatan pula setelah dilakukan penyuluhan dengan persentase $54,3 \%$ menjadi $100 \%$.

Berdasarkan hasil observasi dan wawancara yang telah dilakukan beberapa bulan yang lalu, edukasi masyarakat dan siswa siswi adalah hal pertama yang dilakukan oleh kami. Edukasi ini melingkupi semua lapisan masyarakat/siswa-siswi dan dilakukan secara terus menerus. Isi dari edukasi ini meliputi pemahaman tentang covid-19, makna dari vaksin, sejarah vaksin, tahapan kegiatan vaksin dan manfaat vaksin, serta kegiatan Pretest dan Posttest untuk mengukur pengetahuan. Penekanan pada materi vaksin lebih banyak pada manfaat vaksin hal ini bertujuan agar masyarakat/siswa siswi memiliki kesadaran dari dalam dirinya untuk melakukan vaksin tanpa adanya paksaan dari luar. Edukasi tentang vaksin ini melalui beberapa media seperti media informatika, pamflet,dan sosialisasi.

Menurut (Letuna, 2021) Media informatika dipilih karena banyak lapisan masyarakat/siswa siswi yang saat ini menggunakan media sosial. Media sosial yang sering 
JURNAL PEMBERDAYAAN DAN PENDIDIKAN

KESEHATAN

VOL. 1 NO. 01, DESEMBER 2021

DOI:
Ciptaan disebarluaskan di bawah

Lisensi Creative Commons Atribusi-

NonKomersial-BerbagiSerupa 4.0

Internasional.

dipilih adalah facebook dan whatsApp. Poster menjadi pilihan petugas karena beberapa masyarakat yang lewat bisa dengan mudah membacanya. Sedangkan sosialisasi yang dilakukan oleh kami adalah memberikan edukasi melalui media powerpoint dan poster. Kerjasama yang dilakukan menunjukkan bahwa terdapat upaya nyata yang dilakukan untuk pemberian pemahaman tentang vaksin. Upaya nyata itu berupa pengadaan pemberian vaksin secara gratis dengan bantuan dari pihak Puskesmas yanvg langsung datang ke sekolah. Hal ini bertujuan untuk dapat menjangkau semua lapisan masyarakat agar bisa menerima vaksin.

Berdasarkan hasil pengukuran pengetahuan terhadap siswa siswi MI Yashuda 1 Darma melalui kuesioner pre test dan post test didapatkan hasil tingkat pengetahuan mereka dikategorikan baik. Dibuktikan dengan capaian persentase jawaban dari pertanyaanpertanyaan yang berkaitan dengan Perilaku Hidup Bersih dan Sehat dan kebiasaan mencuci tangan pakai sabun yang sudah mencapai $\geq 75 \%$ dari seluruh pernyataan dalam kuesioner. Sedangkan hasil pengukuran pengetahuan pada siswa siswi MTSN 5 Kuningan pada kuesioner pretest dan posttest terkait vaksinasi didapatkan hasil bahwa nilai pretest dikategorikan cukup dan posttest dikategorikan menjadi baik setelah pemberian edukasi.

Hasil peneltian di atas dapat disimpulkan bahwa menumbuhkan semangat masyarakat untuk berperilaku hidup bersih dan sehat harus dilakukan dengan konsisten dan berkelanjutan serta perlu pemahaman yang lebih terkait mengikuti vaksin akan sangat dibutuhkan pada masa sekarang. Vaksin menjadi salah satu kebutuhan masyarakat untuk mencegah terjadinya infeksi virus yang serius pada manusia. Dengan semangat masyarakat untuk mengikuti vaksin diharapkan menekan angka kematian. Pentingnya menumbuhkan semangat masyarakat dapat membantu pemerintah untuk melakukan pencegahan penyebaran Covid-19 yang terus meningkat. Tenaga kesehatan juga memiliki peran yang sangat penting dalam upaya meningkatkan motivasi dan kesadaran masyarakat untuk melaksanakan vaksin. Pemerintah bekerjasama dengan tenaga kesehatan harus senantiasa memberikan pemahaman kepada masyarakat pentingnya vaksin dan tingkat keamanan vaksin serta perilaku hidup bersih dan sehat (Dahlan, 2021).

\section{KESIMPULAN DAN SARAN}

Kegiatan pemberian Komunikasi Informasi dan Edukasi (KIE) ini dilakukan sebagai upaya pencegahan penularan Virus Covid-19. Mengingat persebaran kasus ini terus 
JURNAL PEMBERDAYAAN DAN PENDIDIKAN

KESEHATAN

VOL. 1 NO. 01, DESEMBER 2021

DOI:
Ciptaan disebarluaskan di bawah

Lisensi Creative Commons Atribusi-

NonKomersial-BerbagiSerupa 4.0

Internasional.

meningkat maka berbagai upaya harus dilakukan guna mengurangi penyebarannya. Kegiatan ini dilakukan pada siswa siswi MI Yashuda 1 Darma dan MTSN 5 Kuningan dengan responden sebannyak 35 orang. Keberhasilan kegiatan ini di nilai melalui persentase jawaban responden terhadap kuesioner atau pre tes pos test yang diberikan. Penilaian pada siswa siswi Ma Yashuda 1 Darma dan MTSN 5 Kuningan melalui persentase dari kuesioner dengan beberapa pernyataan yang diambil seperti yang berkaitan dengan Perilaku Hidup Bersih dan Sehat (PHBS), cuci tangan pakai sabun serta pentingnya vaksinasi. Hasil pengukuran menunjukan bahwa rata-rata capaian persentase dari indikator yang dinilai sebelum diberikan penyuluhan berada pada kategori cukup, sedangkan setelah diberikan penyuluhan terjadi peningkatan capaian persentase menjadi kategori baik. Diharapkan dengan adanya kegiatan ini dapat menumbuhkan pemahaman responden khususnya siswa-siswi agar memahami terkait covid-19 dan vaksinasi. Pihak sekolah pula hendaknya selalu melakukan edukasi yang dapat membuat para siswa lebih paham akan pentingnya vaksinasi.

\section{UCAPAN TERIMAKASIH}

Kami ucapkan terimakasih kepada seluruh pihak yang telah terlibat untuk mensukseskan acara ini baik itu pemerintah desa, masyarakat maupun pihak kampus. Kami berharap semoga kegiatan ini dapat bermanfaat khususnya untuk kami dan umumnya untuk masyarakat lebih luas.

\section{DAFTAR PUSTAKA}

Dahlan, D. N. (2021) 'Upaya Petugas Kesehatan Dalam Menumbuhkan Semangat Vaksin Pada Masyakat (Fenomena Ledakan Minat Vaksin Covid-19) Kota Tulung Agung Jawa Timur.'

Halajur, U. (2018) 'Promosi Kesehatan di Tempat Kerja'.

Letuna, M. A. N. (2021) 'Instragram sebagai Media Edukasi Vaksin Covid-19 di Indonesia.', pp. 88-106.

Litbang.kemkes (2021) 'Tantangan Vaksinasi Covid-19 Di Indonesia'. Available at: https://www.litbang.kemkes.go.id/tantangan-pelaksanaan-vaksinasi-covid-19-diindonesia/.

Mewa Ariani, Adi Setiyanto, dan T. B. P. (2020) 'Dampak Pembatasan Sosial Berskala Besar Terhadap Distribusi Dan Pola Konsumsi Pangan Rumah Tangga’.

Notoatmodjo, S. (2010) Metodologi Penelitian Kesehatan. Jakarta: Rineka Cipta. 
JURNAL PEMBERDAYAAN DAN PENDIDIKAN KESEHATAN

VOL. 1 NO. 01, DESEMBER 2021

DOI:
Ciptaan disebarluaskan di bawah Lisensi Creative Commons Atribusi-

NonKomersial-BerbagiSerupa 4.0

Internasional.

Notoatmodjo, S. (2012) Promosi Kesehatan dan Ilmu Perilaku. Jakarta: Rineka Cipta.

Prastyowati, A. (2020) 'Mengenal Karakteristik Virus SARS-CoV-2 Penyebab Penyakit COVID-19 Sebagai Dasar Upaya Untuk Pengembangan Obat Antivirus Dan Vaksin.', pp. 1-10.

RI, K. (2021) 'survey penerimaan vaksin oleh masyarakat'.

Riyanto., B. dan (2013) Pengetahuan dan Sikap dalamPenelitian Kesehatan. Jakarta: Salemba Medika.

Safitry, R. (2016) 'Gambaran Pengetahuan Mahasiswi tentang Pemberian Vaksin untuk Pencegahan Kanker Serviks di Prodi Kebidanan Fakultas Kedokteran dan Ilmu Kesahatan Universitas Islam Negeri Alauddin Makassar'.

Yusuf (2005) 'Hubungan Aktivitas Fisik Dengan Derajat Hipertensi Pada Lansia', Jurnal Berkala Kesehatan, 1(12), pp. 112-117. 